UDK 347.611-053.2:342.721

Original scientific paper

\title{
MODERN CHALLENGES IN THE IMPLEMENTATION OF THE CHILD'S RIGHT TO KNOW HIS ORIGIN*
}

\author{
Barbara Preložnjak, PhD, Assistant professor \\ Faculty of Law, University of Zagreb, \\ Trg Republike Hrvatske 14, Croatia \\ barbara.preloznjak@pravo.hr
}

\begin{abstract}
The right to know one's origins means the right to know one's parentage, i.e. one's biological family and ascendance and one's conditions of birth. This right raises some of the hardest legal and ethical issues in the case of adopted children, but also in cases of abandoned or displaced children, children conceived by artificial insemination or of children born out of wedlock.

This particular child's right was increasingly debated in recent years, as it conflicts with the right of the biological parent to remain anonymous. The Article 8 of the European Convention on Human Rights, while ensuring respect and protection for private and family life, guarantees at the same time two opposing rights - the right to privacy and the protection of the personal data and the right to know one's origins. This legal solution raises the question whether the right to know the origin in case of children who have reached a certain psycho-physical maturity should prevail when it comes into the conflict with the right of the biological parent to remain anonymous? Although the legal instruments protect both rights, in recent years there is aim to promote the child's right to know their origin rather than the anonymity of the biological parents.
\end{abstract}

To address the issue of conflict between those rights this paper aims to suggest ways in which rights can be balanced against each other to provide the principles guiding the enforcement of the child's right to known his origin in practice.

Keywords: right to know one's origins, right to privacy and the protection of the personal data, the conflict between rights

The author would like to thank Associate Professor Anica Čulo Margaletić, Ph.D., Chair of Family Law, Faculty of Law, University of Zagreb, on constructive comments that improved the manuscript at the time of its emergence. 


\section{INTRODUCTION}

In the past, children were usually being brought up within nuclear families by those they assumed to be their biological parents. ${ }^{1}$ The absence of foolproof methods for establishing genetic links between children and biological parents led to the situations that adopted children, abandoned or displaced children or of children born out of wedlock did not get chance to know their origin. Today, genetic science enables us not only to deepen our knowledge about human origin but also to have children with the help of artificial insemination methods. Although, genetic science helped couples to have offspring's even when they are impaired to have them naturally (i.e. in cases of gamete donation), in legal terms it raised the question whether children in those cases have right to know their genetic origins.

It is now broadly accepted that children who do not know one or both of their biological parents have a "vital interest" to identify them to find out information's about their origin. ${ }^{2}$ The notion of "knowing one's origins" is complex and can have a variety of meanings that may cover several aspects. For example, it can cover the medical aspect (i.e. the right to know one's full family medical history and to know medically relevant genetic information about the donor), the identity aspect (i.e. the right to personal narrative information about the donor that could assist offspring in completing the picture of their own identity) and the relational aspect (i.e. the right to know the full identity of the donor to attempt to establish a relationship with him or her). ${ }^{3}$ Besides the complexity of its meaning, the right of a child to "know his/her origins" can easily come in the conflict with other's rights, in particular the donor's right to autonomy and privacy.

In paper, the author analyzes what is meant by a "right to know the child's origin" and unpack the conflict between the child's right to know and rights of the gamete donor. The special attention will be dedicated to recent developments in the ECtHR's case law that can be helpful in modelling guiding principles in balancing the child's right to know with the rights of the donor.

Fortin, J., Children's right to know their origins - too far, too fast?, Child and Family Law Quarterly, vol. 21, no. 3, 2009, p. 341

2 Besson, S. Enforcing the Child's Right to Know Her Origins: Contrasting Approaches Under the Convention on the Rights of the Child and the European Convention on Human Rights, International Journal of Law, Policy and the Family, vol. 21, Issue 2, 2007, pp. 137-159

3 Ravitsky, V., Knowing where you come from: The Rights of Donor-Conceived Individuals and the Meaning of Genetic Relatedness, Minnesota Journal of Law, Science and Technology, vol. 11, no. 2, 2010, pp. 655-684 


\section{LEGAL RECOGNITION OF THE CHILD'S RIGHT TO KNOW HIS ORIGIN}

According to the interest theory of rights, rights are intermediaries between interests and duties. ${ }^{4}$ It means that "having a right is having one's interests protected in certain ways by the imposition of (legal or moral) normative constraints on the acts and activities of other people concerning the object of one's interests". ${ }^{5}$ If we apply that theory on the right of a child to know his/her origins we can say that this right protects the interest in identity without which one is "deracinated". ${ }^{6}$ In other words, it is the interest of the child to identify where he/she comes from. ${ }^{7}$ It protects interest to know one's biological family and ascendance, or one's conditions of birth which is of greatest concern to those who have been artificially-procreated. ${ }^{8}$ Those children have their biological parentage split from their social or birth parentage and they have legally acknowledged interest to identify where they

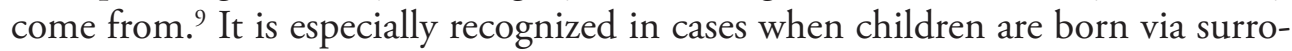
gacy or conceived with the help of the gamete donor. Their interest to be aware of the existence and identity of the persons who contributed to their making is recognized in the United Nations Convention on the Rights of the Child (CRC) and the European Convention on Human Right (ECHR). ${ }^{10}$

\subsection{The United Nations Convention on the Rights of the Child}

Both conventions, CRC and ECHR, deal with the right to know one's origins, but the CRC in Articles 7 and 8 expressly recognized for the first time the right

$4 \quad$ Raz, J., On the Nature of Rights, Mind, vol. 93, no. 370, 1984, pp. 194-214, Raz, J., The Morality of Freedom, Oxford, 1986 p. 181

5 MacCormick, N., Legal Reasoning and Practical Reason, in: French/Ühling/Wettstein (eds), Midwest Philosophical Studies VII: Social and Political Philosophy, Minneapolis, University of Minnesota Press, 1982, p. 271

6 O'Donovan, K., A Right to Know One's Parentage?, International Journal of Law and the Family, International Journal of Law, Policy and the Family, vol. 2, Issue 1, 1988, pp.27-45

7 Bensson, op. cit. note 2, p. 140

$8 \quad$ Ibid. 140.; Freeman, M., The new birth right? Identity and the child of the reproduction revolution, The International Journal of Children's Rights, vol. 4, Issue 3, 1996, p. 277; O'Donovan, K., What Shall We Tell the Children?" Reflections on Children's Perspectives and the Reproduction Revolution; in: Lee, R.; Morgan, D., (eds.), Birthrights: Law and Ethics at the Beginnings of Life, London: Routledge; 1989, p. 96

9 Bensson, op. cit. note 2, p. 140

10 Ibid., p. 138.; Article 43(1) of the UN General Assembly, Convention on the Rights of the Child, 20 November 1989, United Nations, Treaty Series, vol. 1577, p. 3, available at: [https://www.refworld.org/ docid/3ae6b38f0.html] Accessed 20 April 2020; Article 8 of the European Convention for the Protection of Human Rights and Fundamental Freedoms, as amended by Protocols Nos. 11 and 14, 4 November 1950, ETS 5, available at: [https://www.refworld.org/docid/3ae6b3b04.html] Accessed 20 April 2020 
of a child to know his/her parents as a child. ${ }^{11}$ Article 7 of the CRC prescribes that "the child shall be registered immediately after birth and shall have the right from birth to a name, the right to acquire a nationality and, as far as possible, the right to know and be cared for by his or her parents". In the context of the right to know, the term "parents" can be interpreted broadly to include not only social or legal parents but also biological and gestational parents. ${ }^{12}$ Although CRC doesn't explicitly define what the right to know and be cared for by one's parents entails, it might imply the right to contact them but as well as knowledge of their identity. ${ }^{13}$

Further, the CRC require from States Parties to ensure the implementation of these rights following their national law and their obligations under the relevant international instruments in this field, in particular where the child would otherwise be stateless. ${ }^{14}$ In Article 8 CRC prescribes that "States Parties should undertake to respect the right of the child to preserve his or her identity, including nationality, name and family relations as recognized by law without unlawful interference. . .. Where a child is illegally deprived of some or all of the elements of his or her identity, States Parties shall provide appropriate assistance and protection, with a view to re-establishing speedily his or her identity". ${ }^{15}$ Article 8 is mentioning the concept of identity and gives examples of what identity might include (nationality, name, and family relations) without defining it. ${ }^{16}$ However, if we accept the idea that the right to identity is a complex concept that includes right to know one's origins, the State Parties would have duties to register and preserve data regarding a child's biological parentage and to make them accessible to the child. ${ }^{17} \mathrm{~A}$ similar interpretation of the CRC is given by the United Nations Committee on the Rights of the Child (UNCRC) as it interprets that the right to know one's origin

11 Bensson, op. cit. note 2, p. 139

12 Clark, B., A Balancing Act? The Rights of Donor-Conceived Children to Know Their Biological Origins, Georgia Journal of International and Comparative Law, vol. 40, no. 3, 2012, p. 626

$13 \quad$ Ibid., p. 626

14 Article 7 has been consistently criticized by nations that do not allow for such a right or that allow mothers to give birth anonymously (e.g. France). See Ibid., p. 626

15 Article 7 CRC; ; Article 8 was originally proposed to deal with the abuses committed by the military regime in Argentina in the 1970s and 1980s, which abducted infants from their mothers before their births had been registered and illegally gave them to couples associated with the armed forces and the police. See Blauwhoff, R.J., Foundational facts, relative truths: a comparative law study on children's right to know their genetic origins, Utrecht University Repository, 2009, pp. 290-296, 302-305. [https:// dspace.library.uu.nl/handle/1874/34380] Accessed 20 April 2020.;Clark op. cit. note 12, p. 627

16 Freeman thinks that identity is "an organizing framework for holding together our past and our present and it provides some anticipated shape to future life". See Freeman, op. cit. note 8, p. 290; Masson, J.; Harrison, C., Identity: Mapping the frontiers, in Loweand, N.; Douglas, G. (eds.), Families Across Frontiers , The Hague: M. Nijhoff, 1996, pp. 278 - 279; Article 8 CRC

17 Article 8 CRC; Bensson, op. cit. note 2, p. 138 
should include the right of the children to know their genetic identity especially when the children are conceived by artificial insemination. ${ }^{18}$ However, access to data relating to the child's origin, according to Article 3 of the CRC, should be made only if it is in children best interest. ${ }^{19}$ However, if a right of a child to know origin comes into the conflict with rights of their biological parents (e.g. the right to privacy) neither Article 7 nor Article 8 settles the issue of which among the rights should prevail in case of conflict between them. Also, CRC does not provide any criteria for how to balance the child's interests with those of biological parents in case of conflict. Thus the provisions of the CRC relating explicitly to the child's origin do not directly offer any protection to the child's identity. ${ }^{20}$

\subsection{The European Convention on Human Rights}

Unlike CRC, ECHR does not guarantee the right to know one's origins expressly. The right to know one's origin was derived in 1989 by ECtHR in the case Gaskin v. the United Kingdom from Article 8 which guarantees the right to private and family life. ${ }^{21}$ This case concerned Mr Graham Gaskin was taken into care, following the death of his mother less than a year after his birth, by Liverpool City Council from 1959 until 1977 and was boarded out to foster parents. ${ }^{22}$ At the age of 18 , he brought negligence proceedings against the Council and asked for the discovery of his case records. ${ }^{23} \mathrm{He}$ claimed that he was ill-treated in care and sought details of his confidential records from the Council. ${ }^{24}$ The Council released several files in which the contributors gave their consent but refused to release file relating to the whole period in which he had been in care. Mr Gaskin claimed re-

18 UN Committee on the Rights of the Child (CRC), UN Committee on the Rights of the Child: Concluding Observations: Denmark, 15 January 1995, CRC/C/15/Add.33, available at: [https://www.refworld. org/docid/3ae6aec817.html] Accessed 18 May 2020

UN Committee on the Rights of the Child (CRC), UN Committee on the Rights of the Child: Concluding Observations: Norway, 25 April 1994, CRC/C/15/Add.23, available at: [https://www.refworld.org/ docid/3ae6aefe8.html] Accessed 18 May 2020

UN Committee on the Rights of the Child (CRC), UN Committee on the Rights of the Child: Concluding Observations: United Kingdom of Great Britain and Northern Ireland, 9 October 2002, CRC/C/15/ Add.188, available at: [https://www.refworld.org/docid/3df58f087.html] Accessed 18 May 2020

19 Providing information's about the child's origin could be limited in cases when that information's collide with the child's best interest. Clark, op. cit. note 12, p. 629

20 Ronen, Y., Redefining the Child's Right to Identity, International Journal of Law, Policy and the Family, vol. 18, Issue 2, 2004, pp. 147, 160; Clark, op. cit. note 12, p. 628

21 See the case of Gaskin v. United Kingdom, Application no. 10454/83, Judgment of 7 July 1989, Series A, no. 160, 1989

22 Ibid., para. 10

23 Ibid., para. 10

24 Ibid., para. 11 
fusal of access to all his records was a breach of Articles 8 that is protecting private and family life and the right to freedom of expression guaranteed by Article 10 as the State had failed to act to protect his rights. ${ }^{25}$

The ECtHR held that the applicant had a vital interest protected by the Convention in receiving information necessary to know and understand his childhood and early development. ${ }^{26}$ The ECtHR stated that: "[the file] no doubt contained information concerning highly personal aspects of the applicant's childhood, development and history and thus could constitute his principal source of information about his past and formative years. Consequently, the lack of access to the file did raise issues under Article 8" ${ }^{27}$ The ECtHR also stated that: "respect for private life requires that everyone should be able to establish details of their identity as individual human beings and that in principle they should not be obstructed by the authorities from obtaining such very basic information without specific justification". ${ }^{28}$

In determining whether or not the United Kingdom obligation to give Mr. Gaskin access to all information's relevant for his family and private life existed under Article 8, the ECtHR concentrated to find the fair balance that had to be struck between the general interest of the community and the interests of the individual. ${ }^{29}$ The ECtHR also acknowledge that in striking the balance, the limitations of the right to family and private life mentioned in Article 8 may be of certain relevance in cases when "the interests of national security, public safety or the economic well-being of the country, or the prevention of disorder or crime, the protection of health or morals, and the protection of the rights and freedoms of others" demand. ${ }^{30}$

Thus, in deciding whether the interference in Mr. Gaskin case is justified, the ECtHR concentrated on whether a fair balance had been struck between the general interests of the community and the interests of the individual in cases when the contributor's consent is needed to provide access to information contributed by them. The ECtHR was especially concerned to ensure the interests of the individual who is seeking access to records relating to his/her private and family life when

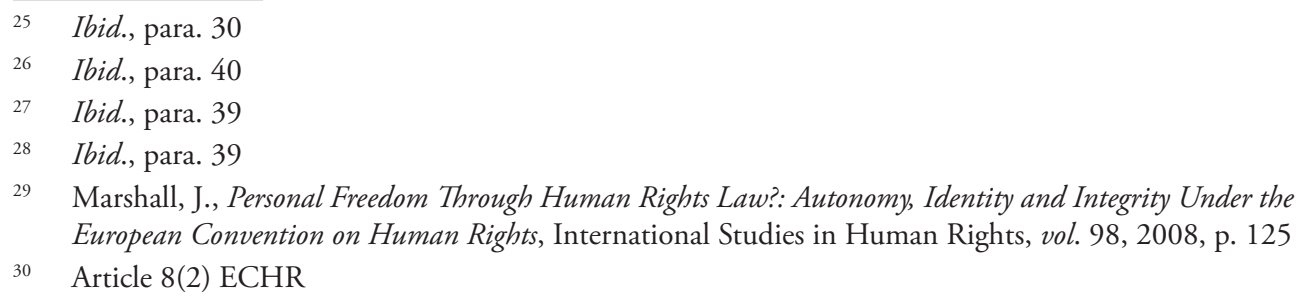


a contributor to the records is not available or is improperly refusing to consent. ${ }^{31}$ In the ECtHR view, such an approach is only in conformity with the principle of proportionality, if it provides that an independent authority finally decides whether to grant access or not in such cases. Therefore, the refusal of the local authority to grant Mr. Gaskin the access to information's, without any kind of independent scrutiny to determine the genuineness of the confidentiality claim, amounted to an infringement of the right to a private and family life in Article $8 .^{32}$ Further, the ECtHR concluded that everyone should be able to establish details of their identity as human beings and that an individual's entitlement to such information is of importance because of its formative implications for his or her personality. ${ }^{33}$

Regarding Article $10 \mathrm{Mr}$ Gaskin's complaint proved unsuccessful as the ECtHR held that Article 10 ECHR did not embody any obligation on the State concerned to impart the information. ${ }^{34}$

After Gaskin case, the ECtHR has ruled violation of Article 8 in sense of right to know one's origin in several other cases such as cases on minors under the guardianship of a public administration and adopted children (Odièvre v. France, 13.2.2003 35 , and Godelli v. Italy $\left.{ }^{36}, 25.9 .2012\right)$, and to justify the provenance of actions and claims to non-marital paternity (Mikulic v. Croatia, 7.2.2002 ${ }^{37}$ ), even

31 Blauwolf, op. cit. note 16, p. 65

32 Ibid., p. 65

33 Although Gaskin case can only with some effort be analogized with the issue of access to one's genetic parentage, as he knew the identity of his genetic parents, the Gaskin case defined the extent to which individuals should be entitled to access files compiled on them by public authorities under Article 8 . Ibid., p. 65

34 The case of Gaskin v. United Kingdom, Application no. 10454/83, Judgment of 7 July 1989, Series A, no. 160,1989 ., para. 51

35 See infra Chapter 3 Para. A. France

36 In the case of Godelli v. Italy the applicant, Ms Godelli, was abandoned by her mother at birth. As her mother did not consent being named, the birth certificate of Ms Godelli did not reveal her name. As adult MsGodelli asked the national courts to disclose the identity of her mother but the national courts denied access to such information, by claiming the necessity to protect the rights of the mother. Ms Godelli claimed that a fair balance had not been struck between her mother's right to confidentiality and her right to know her origins, and that has violated her right to private life. To analyze whether the fair balance was struck between the applicant's right to private life and the legitimate interests of her mother, the ECtHR weighted as follows: On the one hand, the child has a right to know its origins, that right being derived from the notion of private life. Individual's interest in discovering his or her parentage does not disappear with age, quite the reverse. The ECtHR considered that the Italian authorities had failed to strike a fair balance between the interests at stake and, consequently, found a violation of Article 8 of the ECHR. See the case of Godelli v. Italy, Application no. 33783/09, Judgment of 25 September 2012

37 In the case Mikulic v. Croatia the mother of a five-year-old girl claimed on her daughter's behalf that the fact that her daughter had no means of forcing a putative father to submit himself to DNA testing 
beyond the statutes of limitations for these actions stipulated by the national laws (Jäggi v. Switzerland, 13.7.2006 ${ }^{38}$ and Backlund v. Finland, 6.7.2010). ${ }^{39}$

\section{DISPARITIES IN BALANCING THE CHILD'S RIGHT TO KNOW ORIGIN AND DONORS RIGHTS TO PRIVACY}

CRC and ECHR supported by the case law of ECtHR recognized the importance of a child's right to know his/her origin. While broadly declaring a child's right to know his/her origin they are making allowance for adaptation of the right to fit the context of nations with diverse local, political and social cultures. ${ }^{40}$ Thus, CRC calls for "taking due account of the importance of the traditions and cultural values of each people for the protection and harmonious development of the child". ${ }^{41}$ Similarly, the ECHR has regularized this tolerance for local variation by commonly considering whether a state seems incursion on European Convention rights is nevertheless sustainable as within the state's "margin of appreciation". ${ }^{42} \mathrm{In}$ other words, the ECHR leave states with the room to maneuver in adapting rights to local conditions and values or the state's incursion on the individual interest was justified by overriding collective interests. ${ }^{43}$ This zone of discretion within which states can differently interpret their obligations under the ECHR can be illustrated

violated her right to private life under Article 8 of the ECHR since there was no independent authority to which she could submit her paternity claim. The ECtHR held that the right to private life should include the determination of the legal relationship between an extramarital child and her natural father. Croatia needed to put in place procedures to allow her, without unnecessary delay, to obtain certain knowledge of her identity. However, the ECtHR stressed that in each case it is important to strike a balance, recognizing that the father also has a right to privacy that entitles him to avoid forced DNA testing. The case of Mikulic v. Croatia, Application no. 53176/99, Judgement of 7 February 2002

38 In the case of Jäggi v. Switzerland the ECtHR condemned the refusal of Swiss authorities to exhume for the purposes of DNA testing the body of the man the plaintiff claimed was his biological father. The plaintiff sought to establish paternity merely to determine the biological bonds between himself and his presumed father, not to claim any inheritance to which he might have a birthright. While living, the plaintiffs father had always refused to submit to biological testing, despite the suspicions that he was the father. In their brief, the ECtHR notes that "persons seeking to establish the identity of their ascendants have a vital interest, protected by the Convention, in receiving the information necessary to uncover the truth about an important aspect of their identity". The case of Jäggi v. Switzerland, Application no. 58757/00, Judgment of 13 July 2006

39 Farnós Amorós, E., Donor anonymity, or the right to know one's origins?, Catalan Social Sciences Review, vol. 5, Issue 5, 2015, p. 7

40 Woodhouse, B. B., Hidden in Plain Sight: The Tragedy of Children's Rights from Ben Franklin to Lionel Tate, Princeton University Press, 2008, p. 33

41 Preamble CRC

42 Meyer, D. W., Family Diversity and the Rights of Parenthood, in McClain, L.C.; Core, D. (eds.) What Is Parenthood?: Contemporary Debates about the Family; New York University Press, 2016,p. 138

43 Greer, S., The Margin of Appreciation: Interpretation and Discretion Under the European Convention on Human Rights, Council of Europe, 2000, p. 5 
through the case law of the ECtHR where the right to know child's origin was balanced with other's rights such as the right of gamete donor to stay anonymous. It means that the jurisprudence of the ECtHR maintained that the right of a child to know his/her origin is not absolute as sometimes state can give priority to other interests such as "the interests of national security, public safety or the economic well-being of the country, or the prevention of disorder or crime, the protection of health or morals, and the protection of the rights and freedoms of others". ${ }^{44}$ Therefore, there are some important disparities in the enforcement of the right to know the origin between national states. For example, the law in jurisdictions of France and Sweden varies in approach to the issue of conflicting rights of the child and gamete donor. The French law accepts the strict rules on donor's anonymity while the Swedish law very early lifted the donor anonymity rule enabled children to exercise the right to know their origin.

\subsection{France}

In France the parent-child relationship is considered a "purely social construction" and from a legal standpoint, parenthood is perceived as a set of duties that parents are free to take upon themselves if they so wish..$^{45}$ In other words, motherhood and fatherhood are socially determined and biological parenthood is not a source of obligation to care for a child. ${ }^{46}$ Since the French Revolution women have possessed the right to give birth anonymously (accouchement sous X) but the law gives freedom to the birth mothers to end their anonymity at any time. ${ }^{47}$ At first children didn't have the right to access documents revealing the biological mother's name and the possibility of establishing any bond between the mother and the child was generally prohibited. ${ }^{48}$ By coming into force the CRC enabled the children to lift the secret birth on their request and with the assent of the moth-

\footnotetext{
44 Bensson, op. cit. note 2, p. 142

45 Baudouin J.-L., Labrusse-Riou C., Produire l'homme, de quell droit? Étude juridique et éthique des procréation sartificielles, Paris, 1987; Carbonnier, J., Droit et passion du droit sous la Ve République, Flammarion, 1996, pp 248-250; and Dekeuwer-Defossez, F., Renover Le Droit de La Famille : Propositions Pour Un Droit Adapte Et Aux Aspirations de Notre Temps, Documentation Francais, 1999

46 Eekelaar, J., Parenthood, Social Engineering and Rights, in: Morgan, D.; Douglas, G. (eds.), Constituting Families; a Study in Governance, Franz Steiner Verlag Stuttgart, 1994, pp 80-97

47 Blauwhoff, op. cit. note 16, p. 196

48 For presumption of parentage see Articles 311-319 of the Civil code (Code Civil). Article 341-1 of the Civil code (Code Civil) prescribed that "After a child's birth his/her mother may request that the secrecy as to her admission to hospital and identity be preserved". [https://www.legifrance.gouv. fr/affichCode.do;jsessionid=2EACFC55F81B97B6B38B1080C0E4929D.tplgfr41s_3?cidTexte=LEGITEXT000006070721\&dateTexte $=20080225]$ Accessed 20 April 2020. Births registered under X totaled approximately 550 in 2002 and in 2004 they allegedly numbered around 600. Blauwhoff, op. cit. note 16, p. 201
} 
er. ${ }^{49}$ However, access to knowledge of child origin has no bearing on "the rights or responsibilities of anyone concerned" as the discovery of birth mother and birth father had "absolutely no impact on the individual's civil status and maternity or paternity". ${ }^{50}$ Thereby, the law gave acknowledgement that biological origins may be valuable as such, without being absorbed into the legal category of birthright. ${ }^{51}$

It is interesting to notice that French law which favors birth mother's anonymity is supported by rulings of the ECtHR. In the case of Odièvre v. France the petitioner, adopted at the age of four, claimed that right to know origin is breached as she did not have access to information about the circumstances in which she was born and abandoned that would help her to identify the birth mother as French social services had refused to release that information to her. ${ }^{52}$ She had obtained access to certain information about her biological mother from her adoption records, but they were insufficient to identify the mother. ${ }^{53}$ The ECtHR tested whether it was reasonable to impose on the French state a positive obligation to force the birth mother to divulge her identity. ${ }^{54}$ In other words, the ECtHR was trying to determine the limit of the reasonable steps necessary to be taken by the state to secure the applicant's rights under Article 8(1). ${ }^{55}$ Although the ECtHR took care to note that "birth, and in particular the circumstances in which a child is born, forms part of a child's, and subsequently the adult's, private life guaranteed by Article 8 of the ECHR", it ruled that the French law that gives the right to mother to give birth anonymously was sufficient to ensure a fair balance between the protection of the privacy of the biological mother, who had given birth anonymously, and the child's interest in having access to the identity of his biological parents. ${ }^{56} \mathrm{Al}$ though, the judgment is consistent with ECtHR case-law that "takes into consideration a wide margin of appreciation concerning complex issues where generally there is little common ground between them due to lack of a uniform approach or to the transitional state of the law on these issues", the ECtHR gave an overly

49 Blauwhoff, op. cit. note 16, p. 120-121

50 Article L147-7 of the Social Action and Families Code (Code de L'action Sociale et des Familles). [https:// www.legifrance.gouv.fr/affichCodeArticle.do?idArticle=LEGIARTI000006796699\&cidTexte=LEGITEXT000006074069\&dateTexte=20020123] Accessed 20 April 2020

51 Brunet, L.; Kunstmann, J-M., Gamete donation in France: the future of the anonymity doctrine, Medicine, Health Care, and Philosophy, vol. 16, no. 1, 2013, p. 77.

52 The case of Odièvre v. France, Application no. 42326/98, Judgement of 13 February 2003, para. 28

53 The case of Odièvre v. France, Application no. 42326/98, Judgement of 13 February 2003, para. 48

54 The case of Odièvre v. France, Application no. 42326/98, Judgement of 13 February 2003, para. 45

55 The case of Odièvre v. France, Application no. 42326/98, Judgement of 13 February 2003, para. 45.; Steiner, E., Desperately Seeking Mother - Anonymous Births in the European Court of Human Rights, Child and Family Law Quarterly, vol. 15, no. 4, 2003, p. 439

56 The case of Odièvre v. France, Application no. 42326/98, Judgement of 13 February 2003, paras. 4445 
large discretion in this case to the French state. ${ }^{57}$ Moreover, as French rules on anonymous births are an oddity when compared and contrasted to the rules and accepted practices on birth registration commonly applied in the vast majority of European jurisdictions where entry of the mother's name on the child's birth certificate is compulsory. ${ }^{58}$ ECtHR judgment in Odièvre v. France case also suffers from a further flaw as it keeps silent on international instruments, especially Article 7 of the CRC which provides for registration of a child after birth and rights to the name, nationality and, "as far as possible", the right to know and be cared by his parents. ${ }^{59}$

Unlike children born for mother that choose to stay anonymous, children conceived with donated gamete can't even access any information about their biological parent(s) as France is among rare states in the European Union (EU) that respect the donor's anonymity. ${ }^{60}$ The rule of donor's anonymity was introduced in France in 1994 as an amendment to Public Health Code (Code de la santé publique) and preserved for lack of debate even when the laws were revised in $2004 .^{61}$ According to Articles L.12115 and L. 1244-7 of the Public Health Code (Code de la santé publique): "No information enabling the identification of either the person who donated a component or a product of his or her body, or the person who received it, shall be divulged. The donor shall not know the recipient's identity; the recipient shall not know the donor's identity. In case of therapeutic necessity, only

57 Steiner, op. cit. note 55, p. 441.; The principle of anonymous birth has most recently been reiterated in the legislative reform of 2002. However, the legislation also aims (i) to encourage the medical team to persuade mothers to keep their babies and to inform them of welfare aid available; and (ii) to improve the situation of children born to anonymous mothers to facilitate and encourage the transmission of information concerning their genetic origins. See Law no. 93-22 of $8^{\text {th }}$ January 1993 (Loi $n^{\circ}$ 93-22 du 8 janvier 1993 modifiant le code civil relative à l'état civil, à la famille et aux droits de l'enfant et instituant le juge aux affaires familiales, JORF ${ }^{\circ} 7$ du 9 janvier 1993, p 495) inserting Articles 341 and 341-1 Civil Code (Code civil) and the Law no. 2002- 93 of 22 ${ }^{\text {nd }}$ January 2002 (Loi $n^{\circ} 2002-93$ du 22 janvier 2002 relative à l'accès aux origines des personnes adoptées et pupilles de l'Etat) relating to access by adopted persons and people in State care to information about their origins. [https://www.legifrance.gouv.fr/ affichTexte.do?cidTexte=JORFTEXT000000361918\&categorieLien=id] Accessed 20 April 2020

58 For example, in England and Wales under the Births and Deaths Registration Act 1953, section 2 recognized a legal duty of mother and father when married to register a child's birth in their name; the obligation falling on the mother to enter her name in the register if she is not married. Germany has similar provisions in the 1937 Personenstandsgesetz, sections 16-18 of which regulate the civil status. Similar cases we may find in Norway, Denmark, Netherlands, Belgium, Switzerland, Spain and Portugal. Italy and Luxembourg do not make it mandatory for the mother's name to be entered on the birth certificate. Steiner, op. cit. note 55, p.441

59 Steiner, ibid., p.447

60 Rules of donor's anonymity we may find as well in Belgium, Spain, Portugal, Greece, Denmark, Bulgaria, Czech Republic. Brunet, L., Donors anonymity and right to access to personal origin, Council of Europe, 2018, p. 3. [www.eshre.eu >05_BRUNET_NEW] Accessed 20 April 2020

61 Brunet; Kunstmann, op. cit. note 51, p. 69 
the donor and recipient's physicians shall be entitled to have access to information enabling their identification". ${ }^{62}$ With this rule of anonymity, the legislator had an aim to keep donor and recipient from knowing each other's identity to prevent the existence of a market, where such human-body products as gametes could be traded by private agreement. ${ }^{63}$

The parentage of donor offspring is established in a special legal procedure, whereby in the chambers of a judge or notary public, the sterile couples sign consent to the intervention of a donor as a third party. ${ }^{64} \mathrm{Within}$ this procedure parental rights are established for the sterile couple and they are informed of the duties incumbent upon them as the legal parents of the child to be born. ${ }^{65}$ According to Article 16-8 of the Civil code (Code Civil): "In case of therapeutic necessity, only the donor and recipient's physicians shall be entitled to have access to information enabling their identification" ${ }^{66}$ A similar rule is contained in Article L. 1244-6 of the Public Health Code (Code de la santé publique), stating that: "The authorized bodies and establishments, under the provisions of Article L. 2142-1, provide health authorities with appropriate information on the donors. A physician may access no identifying medical data in case of therapeutic necessity relative to a child born through reproductive technologies, using donated gametes" ${ }^{67}$ According to the Article L. 1131-1-2 and R. 1131-20-3 of the Public Health Code (Code de la santé publique) the physician should provide the concerned children with information's about the serious genetic disorder and invite them to genetic counseling. ${ }^{68}$ This kind of regulation provided parents with the freedom to keep the procedure between them or to inform the child about the details of conception. ${ }^{69}$ Also, the rule of donor anonymity made easier to attract donors as they were not obligated to assume parenthood for the children who are conceived from their sexually reproductive cells. ${ }^{70}$

However, donor's anonymity resulted with the locked filial relationship of the child with the couple receiving the donation and donor's existence ends up being

\footnotetext{
62 Articles L.12115 and L. 1244-7 of the Public Health Code (Code de la santé publique). [https://www. legifrance.gouv.fr/affichCode.do?cidTexte=LEGITEXT000006072665] Accessed 20 April 2020

63 Brunet; Kunstmann, op. cit. note 51, p. 70

64 Ibid., p. 70

65 Articles 311-19 and 311-20 Civil code (Code Civil)

66 Articles 311-19 and 311-20 Civil code (Code Civil)

67 Article L. 1244-6 Public Health Code (Code de la santé publique)

68 Article L. 1131-1-2 and R. 1131-20-3 Public Health Code (Code de la santé publique)

69 Brunet; Kunstmann, op. cit. note 51, p. 72

$70 \quad$ Ibid., p. 72
} 
concealed as the child is divested of any right to trace him or her. ${ }^{71}$ Although French rule of donor's anonymity was firstly recommended as an example and followed throughout Europe, the rule had been condemned by the psychoanalysts, child psychiatrists, and sociologists concerned about the effect it would have on the individual born from the donation. ${ }^{72}$ Nevertheless, the rule prevailed in France which imposes the question of whether children conceived this way should, as those who were born from anonymous parents, have the same right of access to identifying information about their genetic background which is under the protection of personal autonomy contained in the right to respect for private and family life regulated by Article 8 of the ECHR. ${ }^{73}$ The recent French and ECtHR case law confirms the need for change in the French legislature. Thus, in cases Sillau v.France and Gauvin-Fournis v. France, which were communicated to the Government in June 2018, the applicants were born as a result of artificial insemination using donor sperm. ${ }^{74}$ When they reached adulthood their parents told them how they had been conceived. ${ }^{75}$ The applicants then took steps to discover the identity of their respective biological fathers (or obtain certain non-identifying information) but their efforts were thwarted by the legal rules on gamete donation, as French law prohibits the disclosure of the donor's identity and only doctors are permitted to provide certain non-identifying information, for the purposes of treatment. ${ }^{76}$ The French State Council (Conseil d'Etat) has taken the view that the rule on the donor's anonymity is designed to protect the private and family life of donors, recipients and their families, and that the legislature made a balanced

$71 \quad$ Ibid., p. 70

72 Ibid., p. 70, Widlöcher, D.; Tomkiewicz S., Actes du Colloque "Génétique, procréation et droit», Paris: Actes Sud, 1985, pp. 44, 546; Vacquin, M., Filiation et artifice, Le Supplément, 1991, pp. 130-149; Delaisi de Parseval, G.; Verdier, P., Enfant de personne, Paris: Odile Jacob, 1994, chap. 5.; Cadoret, A.et al.,Les lois du silence, Libération, 2003, p. 39

73 For further elaboration, see Brunet, L. Le principe de l'anonymat du donneur de gamétes a' l'épreuve de son contexte. Analyse des conceptions juridiques de l'identité. in:Jouannet, P.;Mieusset, R. (eds.), Donner et aprés? La procréation par don de spermatozoïdes avec ou sans anonymat, Berlin: Springer, 2010, p. 235; Brunet, L., Des usages prote iformes de la nature: Essai de relecture du droit franc a ais de la filiation, in:Bonte, P.; Porqueres, E.; Wilgaux, J. (eds.), L'argument de la filiation. Aux fondements des sociétéseuropéennes et me'diterrane'ennes, Paris: Maison des sciences de l'homme, 2011, pp. 285-323

74 The case of Gauvin-Fournis v. France, Application no. 21424/16. Application communicated to the French Government on 5 June 2018. [https://hudoc.echr.coe.int/eng\#\{\%22itemid\%22:[\%22001-184370\%22]\}] Accessed 20 April 2020; The case of Silliau v. France, Application no. 45728/17. Application communicated to the French Government on 5 June 2018. [https://hudoc. echr.coe.int/fre\#\{\%22itemid\%22:[\%22001-184371\%22]\}] Accessed 20 April 2020

75 Para. 3 the case of Gauvin-Fournis v. France, Application no. 21424/16.; Para. 3 the case of Silliau v. France, Application no. 45728/17

76 Para. 6-7 the case of Gauvin-Fournis v. France, Application no. 21424/16.; Para. 5 the case of Silliau v. France, Application no. 45728/17 
assessment of the risks inherent in lifting secrecy. ${ }^{77}$ The applicants maintain that rule infringe their right to be informed of their origins and are discriminatory. ${ }^{78}$

Regarding the need of a change of legislation that supports the strict rule of anonymity the French State Council (Conseil d'Etat) invited the legislator to open the debate. ${ }^{79}$ In the end of 2019 the new legislation has been proposed to loosen the strict rule of donor's anonymity. It has been suggested, as in many other countries, that right to know origin should be open to all children that have reached the age of majority and who want to learn more about their donors. ${ }^{80}$ According to the proposed amendment donors would have the freedom to choose whether they reveal their identity and will be asked before the donation to accept providing irrevocable access to non-identifying data, available upon request to individuals born as a result of the donation after they turn 18. "This proposed mechanism has an aim to preserve in a more balanced way the interests of the person born from a donation of gametes (access to origins), those of the donor (the donor's right to private life for themselves and their relations) and the general interest (to not discourage gametes donors)" ${ }^{81}$

In February 2020 the French Senate (Sénat) debated on lifting the anonymity for gamete donors. ${ }^{82}$ Although the initial draft that stipulated that the donor had to reveal his identity if the child requested it when he is 18 was approved by the $\mathrm{Na}$ tional Assembly (Assemblée nationale) during the first reading, the Senators have amended it to allow the donors the prerogative of whether or not to disclose his identity upon the child's request. ${ }^{83}$ As a result of this significant modification, the

77 Para. 11, 21 the case of Gauvin-Fournis v. France, Application no. 21424/16.; Para. 9 the case of Silliau v. France, Application no. 45728/17

78 Para. 27 the case of Gauvin-Fournis v. France, Application no. 21424/16.; Para. 11 the case of Silliau v. France, Application no. 45728/17

79 Leroyer, A-M., Why should France change its legislation relating to donor anonymity?, 2016, pp. 23-24, [ejournals.lib.auth.gr] Accessed 20 April 2020. (This is a prospective comparative study performed for the report ordered by the Minister of Family Law in February 2014, published under the Title: Théry, I.;Leroyer, A.M., Filiation, Orgine, Parentalité, Paris, 2014. [http://www.justice.gouv.fr/include_htm/ etat_des_savoirs/eds_thery-rapport-filiation-origines-parentalite-2014.pdf] Accessed 20 April 2020

$80 \quad$ Ibid., p. 18

81 Loibioéthique: que reste-t-il du projet de loi qui arrive au Sénat?, 2020, [https://www.france24.com/ fr/20200120-loi-bio\%C3\%A9thique-que-reste-t-il-du-projet-de-loi-qui-arrive-au-s\%C3\%A9nat] Accessed 20 April 2020

82 French Bioethics: Main Revisions Adopted by the Senate during First Reading, 2020, [https://www.alliancevita.org/en/2020/02/french-bioethics-main-revisions-adopted-by-the-senate-during-first-reading/] Accessed 20 April 2020

Ibid. 
lifting of anonymity, unfortunately, will not have much impact on the child's right to know his/her origin. ${ }^{84}$

\subsection{Sweden}

Sweden was the first jurisdiction in the world to allow a child born through artificial insemination with a donor's gamete to find out the identity of the donor when he/she reaches maturity. ${ }^{85}$ Adoption of legislation that aimed to protect child right to know origin was initiated in 1981 by Haparanda case which served as a catalyst for a nationwide controversy over donor insemination. ${ }^{86}$ In this case, a boy conceived through donors insemination was declared "fatherless" by a Swedish lower court in the northern town of Haparanda. ${ }^{87}$ The boy's mother and social father had divorced a few years after his birth, at which point the father denied paternity to avoid financial responsibility for the child, claiming that he had not consented to the insemination. ${ }^{88}$ The court decision in his favor of the father wound its way up to the Supreme Court, which upheld the previous decision. ${ }^{89}$ The case was viewed as a precedent for dealing with retracted paternity and it demonstrated the possibility that children conceived by donor's gamete become fatherless. ${ }^{90}$ As there was no legal solution that would prevent these situations, a government commission of inquiry was established to study the issue and make policy recommendations. ${ }^{91}$ In 1985 the Swedish parliament adopted the Act on Insemination (SFS 1984:1140) with the notion that secrecy and lack of access to donor information were not in the best interests of the child..$^{92}$ Originally, the provisions of Act on Insemination

84 Ibid.

85 Ekerhovd, E.; Faurskov, A.; Werner, C., Swedish Sperm Donors Are Driven by Altruism, but Shortage of Sperm Donors Leads to Reproductive Travelling, Uppsala journal of medical sciences, vol. 113, no. 3, 2008, p. 305

86 Liljestrand, P., Legitimate State and Illegitimate Parents: Donor Insemination Politics in Sweden, Social Politics: International Studies in Gender, State \& Society, vol. 2, Issue 3, 1995, p. 270

$87 \quad$ Ibid., p. 276

88 Ibid., p. 276

89 Ibid., p. 276

$90 \quad$ Ibid., p. 276

$91 \quad$ Ibid., 277

92 Daniels, K.; Lalos, O., The Swedish insemination act and the availability of donors, Human Reproduction, vol.10, no.7, 1995, p. 1873; The Act on Insemination (Lag om insemination, SFS 1984:1140) complied with the later implemented CRC and its Article 7 which regulates the child's knowledge about its origin. [https://www.riksdagen.se/sv/dokument-lagar/dokument/svensk-forfattningssamling/ lag-19841140-om-insemination_sfs-1984-1140] Accessed 20 April 2020. Isaksson, S., The child's best interest: Perspectives of gamete recipients and donors, Digital Comprehensive Summaries of Uppsala Dissertations from the Faculty of Medicine 1152, Uppsala University, 2015, p.19. [https://uu.diva-portal. org/smash/get/diva2:862603/FULLTEXT01.pdf] Accessed 20 April 2020 
(Lag om insemination) were governing access to identifying information applied only to sperm donation since egg donation was unlawful until $2003 .{ }^{93}$

Today, this law is integrated into a wider legal framework called the Genetic Integrity Act (Lag om genetisk integritet) which not only regulates artificial insemination by gamete donors but also in vitro fertilization, genetic research, handling human embryos and so forth. ${ }^{94}$ According to Chapter 6, Section 5 and Chapter 7 of the Genetic Integrity Act (Lag om genetisk integritet) the child has right to access the data on the donor recorded in the hospital's special journal if he/she has been conceived through donor treatment procedure, and when he/she has reached sufficient maturity. ${ }^{95}$ The legal parents and donors have no right to identifying information about each other and donors have no right to know the identity of

93 The Act on Insemination (Lag om insemination, SFS 1984:1140) was proclaimed on 20 December 1984. In 2003, the IVF Act (Lag om befruktning utanfor kroppen,SFS 1988:711) was amended to permit egg or sperm donation in combination with IVF under certain limited circumstances. [https:// riksdagen.se/sv/dokument-lagar/dokument/svensk-forfattningssamling/lag-1988711-om-befruktning-utanfor-kroppen_sfs-1988-711] Accessed 20 April 2020.Today, the Genetic Integrity Act (Lag om genetisk integritet, SFS 2006:351) contains two prohibitions particularly relevant to the best interests of donor offspring and their right to identifying information about the donor: the prohibition against the importation of sperm and the prohibition against using the gametes of dead donors. Besides, the regulations on assisted conception prohibit the mixing of gametes in a treatment procedure. Stoll, J., Swedish donor offspring and their legal right to information, Uppsala Universitet, Sweden, 2008, p. 59. [https://www.diva-portal.org/smash/get/diva2:398198/FULLTEXT01.pdf] Accessed 20 April 2020

94 The Genetic Integrity Act (Lag om genetisk integritet, SFS 2006:351). [https://www.riksdagen.se/sv/ dokument-lagar/dokument/svensk-forfattningssamling/lag-2006351-om-genetisk-integritet-mm_sfs2006-351] Accessed 20 April 2020. The Genetic Integrity Act (Lag om genetisk integritet) also repealed, and subsequently consolidated, the following acts: Act Concerning the use of Certain Genetic Technology in Medical Screening (Lag om användning av vissgenteknik vid allmänna hälsoundersökningar,SFS 1991:114); and Act Concerning Measures for Purposes of Research or Treatment Involving Fertilised Human Ova (Lag om ätgärder i forsknings- ellerbehandlingssyfte med ägg frän människa, SFS 1991:115). [https://www.riksdagen.se/sv/dokument-lagar/dokument/svensk-forfattningssamling/ lag-1991114-om-anvandning-av-viss-genteknik_sfs-1991-114]; [https://www.riksdagen.se/sv/dokument-lagar/dokument/svensk-forfattningssamling/lag-1991115-om-atgarder-i-forsknings--eller_sfs1991-115] Accessed 20 April 2020.

95 Ch 6, s 5 (Insemination); Ch 7, s 7 (IVF)., Stoll, op. cit. note 93, p. 44; Regarding the meaning of sufficient maturity, if an adult person wants to access information's about his donor, sufficient maturity is presumed. In the case when the child is under 18 years of age, access to information's must first be evaluated by the National Board of Health and Welfare (Socialstyrelsen) to establish whether or not they are sufficiently mature to know the identity of the donor. Requirements for sufficient maturity would generally be fulfilled when the child was in the upper teens. Regarding the meaning of sufficient maturity, if an adult person wants to access information's about his donor, sufficient maturity is presumed. In the case when the child is under 18 years of age, access to information's must first be evaluated by the National Board of Health and Welfare (Socialstyrelsen) to establish whether or not they are sufficiently mature to know the identity of the donor. Requirements for sufficient maturity would generally be fulfilled when the child was in the upper teens. Stoll, op. cit. note 93, p. 46 
the child. ${ }^{96}$ According to the Genetic Integrity Act (Lag om genetisk integritet) the child has right to access the data only if it was conceived either in a publicly funded Swedish hospital or an institution authorized by the National Board of Health and Welfare (Socialstyrelsen) to perform artificial insemination procedures. ${ }^{97} \mathrm{It}$ follows that children conceived with the help of donors gamete through private arrangements or following treatment procedures carried out abroad have no right to information about the donor under the Genetic Integrity Act (Lag om genetisk integritet).${ }^{98}$ However, if the child has reason to suspect that he/she was conceived through a donor treatment procedure the National Board of Health and Welfare (Socialstyrelsen) is obliged to, on request, help him/her find out if there is any information recorded in a special medical record. ${ }^{99}$

The child to be able to seek out the genetic origin, besides the sufficient maturity, needs to have information that he/she is conceived by donor treatment procedure and the records need to be preserved. ${ }^{100}$ However, the law does not require the parents to tell the child about its biological origin. It is recommended that they discuss the matter of family formation at 3-6 years of age. ${ }^{101}$ When the question of origin arises from the child in the teenage years, it is recommended that the parents, as in all other matters, respect the integrity of the child and give an honest answer. ${ }^{102}$ If records are not preserved the child's right to access information's about the donor would be worthless. As well, the Genetic Integrity Act (Lag om

\section{Stoll, ibid.}

97 Chapter 6, section 2 (Insemination); Chapter 7, section 4(1) (IVF) the Genetic Integrity Act (Lag om genetisk integritet)

98 Stoll, J., op. cit. note 93, p. 45

${ }_{99}$ Chapter 6, section 5 (Insemination); Chapter 7, section 7 (IVF) the Genetic Integrity Act (Lag om genetisk integritet); Stoll, ibid., p. 44

100 Stoll, ibid., p. 44; A Swedish study of DI parents in 1998 found that a small majority (52\%) stated that they had either told $(11 \%)$ or intended to tell (41\%) their children. Among the rest, $19 \%$ were not intending to tell their children, $18 \%$ were uncertain and $11 \%$ did not answer the question. Two Swedish studies on parents of donor insemination-conceived children (conducted since the introduction of the 1985 legislation) found that, $20 \%$ of parents had told their children (age: 1-15 years) about the donation. In a follow-up of the first study, more than half of the parents had told their offspring (first child aged 5-15 years) about the donation, but it was less common to inform the child about his/her right to obtain information about the donor's identity. Isaksson, S. et al., Two decades after legislation on identifiable donors in Sweden: are recipient couples ready to be open about using gamete donation?. Human Reproduction, vol. 26, no. 4, pp. 2011, p. 854

101 Daniels, K., The Swedish Insemination Act and Its Impact, The Australian and New Zealand Journal of Obstetrics and Gynecology, vol. 34, no. 4, 1994, p. 438

102 Daniels, ibid., p. 438 
genetisk integritet) stipulates that information about the donor is recorded in a special medical record which shall be preserved for at least 70 years. ${ }^{103}$

All above mentioned provisions secure that right to know origin for all Swedish children conceived with donor's gamete are protected in according to the requirements of international law (CRC and ECHR).

\section{RIGHT TO KNOW THE CHILD'S ORIGIN IN CROATIA}

Medically assisted procreation with donor's gamete has been firstly regulated by the Act Concerning Medical Measures for Exercising the Right to Free Decision about Giving Birth to Children which was in force since 1978. ${ }^{104}$ The Act allowed artificial insemination with donor's gamete to an adult and a healthy woman at an age suitable for birth. ${ }^{105}$ However, the legislator did not foresee the right for the child to know his/her origin. In other words, the child conceived with donors gamete did not have the claim right against the donor regarding the provision of the data about his/her origin. As well, the health care workers which provide services of medically assisted procreation had the obligation to keep as a secret the data of the donor's identity, the identity of the artificially fertilized woman and her husband. ${ }^{106}$

It is interesting to notice that even though the Act deprived the child of his/her right, there was no case-law on the subject of breaching child's right to know his/her origin. ${ }^{107}$ The only case law in Croatia which was the subject of ECtHR judgment concerned a child born out of wedlock who, together with her mother,

103 Chapter 6, section 4 (Insemination); Chapter 7, section 6 (IVF) the Genetic Integrity Act (Lag om genetisk integritet); Before the Act on Insemination (Lag om insemination) came into force in 1985, record keeping associated with donor treatment procedures was arbitrary and the possibility for donor offspring to discover that they were born through insemination or find out the identity of the donor was very small. All documents concerning insemination treatment were either destroyed or inaccessible to anyone other than the responsible doctor, largely in an attempt to keep the information secret from the child. Stoll, op. cit. note 93, p. 49

104 The Act on Health Measures Related to Right to the Enjoyment of Free Choice in Childbirth (Official Gazette No. 18/78, 31/86, 47/89)

105 If a woman is married, artificial insemination with another man's semen can be performed only with the consent of her spouse. See Article 33 of the Act on Health Measures Related to Right to the Enjoyment of Free Choice in Childbirth

106 Article 32 of the Act on Health Measures Related to Right to the Enjoyment of Free Choice in Childbirth

107 Steering Committee of Bioethics (CDBI), Strasbourg, 9 February 2012, p. 86, available at: [https:// www.coe.int/t/dg3/healthbioethic/texts_and_documents/INF_2005_7\%20e\%20REV2\%20MAP. pdf] Accessed 13 May 2020 
filed a paternity suit. ${ }^{108}$ In this case, the mother claimed on her daughter's behalf that the fact that her daughter had no means of forcing a putative father to submit him to DNA testing violated her right to private life under Article 8 of the ECHR since there was no independent authority to which she could submit her paternity claim. ${ }^{109}$ The ECtHR held that the right to private life should include the determination of the legal relationship between an extramarital child and her natural father. ${ }^{110} \mathrm{Also}$, the ECtHR stressed that it is important to strike a balance by recognizing that the father also has a right to privacy which entitles him to avoid forced DNA testing. ${ }^{111}$ Due to respect for private life, according to ECtHR, everyone should be able to establish details of their identity as individual human beings and entitlement to such information is important because of its formative implications for individual's personality. ${ }^{112}$ Consequently to the judgment, Croatia needed to put in place procedures to allow the child, without unnecessary delay, to obtain certain knowledge of his/her identity. ${ }^{113}$

As a response to the ECtHR finding some legislative measures had been taken regarding the right of the child to know his/her origin in the case when mother or father are refusing to take medical tests to establish a legal relationship with the child. For instance, the Family Act that was enacted in 2003 in Article 292 prescribed that national court may request medical tests to establish a parent-child relationship and when the mother or father refuses to undergo medical tests or fail to appear at the appointment, the court will take that notion into account while giving a judgment. ${ }^{114}$ Thus, the legal consequence of refusing cooperation by not attending a medical examination to establish paternity/maternity were deemed as evidence in favour of the opposing side.

Although some legal steps had been taken to protect child' right to know his/her origin, the children who were conceived by donated gamete stayed deprived of knowing their origin till July 2009 when the Act on Medically Assisted Procreation was enacted and articles that were regulating the donation of gamete in the

108 The case of Mikulic v. Croatia, Application no. 53176/99, Judgement of 7 February 2002

109 Paras. 8, 47, 56, 64 of the case of Mikulic v. Croatia, Application no. 53176/99, Judgement of 7 February 2002

110 Paras. 53-55 of the case of Mikulic v. Croatia, Application no. 53176/99, Judgement of 7 February 2002

111 Para. 65 of the case of Mikulic v. Croatia, Application no. 53176/99, Judgement of 7 February 2002

112 Para. 54 of the case of Mikulic v. Croatia, Application no. 53176/99, Judgement of 7 February 2002

113 Paras. 64-65 of the case of Mikulic v. Croatia, Application no. 53176/99, Judgement of 7 February 2002

114 See Article 292 of the Family Act (Official Gazette No. 16/03, 17/04, 136/04, 107/07, 57/11, 25/13, 05/15; hereinafter Family Act 2003). The same provision is kept in Article 390(6) of the Family Act (Official Gazette No. 103/15, 89/19; hereinafter: Family Act 2015) 
Act Concerning Medical Measures for Exercising the Right to Free Decision about Giving Birth to Children were repealed. ${ }^{115}$ The reason for prolonged passing of the law that regulates right to know in case of gamete donation was the fact that the legislator had one of the most difficult tasks to find "appropriate solutions in the field of reproduction and bioethics while offering values in a national community". ${ }^{116}$ Guided by the principle of the protection of the participants in procedures of gamete donation and the principle of the state's control of the hospitals, which undertake the procedures of medically assisted procreation, the Act on Medically Assisted Procreation 2009 enabled a child born from a donated gamete to inspect the register of data on conception and donors that was kept at the State Register on Medical Fertilization of the Ministry of Health. ${ }^{117}$ Exceptionally, the Act enabled child's legal representative or child's physician to have access to the State Register in cases when it is necessary because of the medical reasons or if reviling the data is in the best interest of the child and if it is previously approved by the National Commission for Medical Fertilization. ${ }^{118}$ In November 2009 the access to data on conception was restricted by amendment of the Act which prescribed that access to data on donor's identity is accessible only if the donor gave his/her approval to access the data before donation of gamete. ${ }^{119}$ In other words, without the consent of the donor, the child would still be deprived of the right to know his/her origin. As such provision aimed to protect the donor instead of the child; we may say that the legislator simply lost from his sight the best interest of the child. ${ }^{120}$

To harmonize Croatian legislation with the Article 7(1) of the CRC which prescribes "child's right to know his/hers parents, as far as possible", the new Act on Medically Assisted Procreation was enacted in 2012. ${ }^{121}$ The Act aims more to protect child's right to know his/her origin by prescribing in Article 13 right of the

115 Act on Medically Assisted Procreation (Official Gazette No. 88/09; hereinafter: Act on Medically Assisted Reproduction 2009)

116 Korać, A., Draft of the Croatian Act on Medically Assisted Procreation - Balancing Procreative Rights, Društvena istraživanja: časopis za opća društvena pitanja, vol. 8, no. 2-3, 1999, p. 230-231

117 Ibid. The child can access the data about the donor when he/she reaches the age of majority. Art. 10(2) Act on Medically Assisted Procreation 2009

118 Article 10(3), 41 of the Act on Medically Assisted Procreation 2009

119 Professor Dubravka Hrabar assumes that behind the resistance to "open identity" of donors data stands fear of a reduction in the number of gamete donations, which has happened in some European countries. Hrabar, D., Pravni dosezi medicinske oplodnje u Hrvatskoj, Zbornik Pravnog fakulteta u Zagrebu, vol. 60, no. 2, 2010, p. 433; Article 3(2) AmendmentoftheAct on Medically Assisted Procreation (Official Gazette No. 137/2009)

120 Hrabar, op. cit. note 119 , p. 433,440

121 The Final Draft on the Act on Medically Assisted Procreation, Government of the Republic of Croatia, p.44, available at: [https://vlada.gov.hr/UserDocsImages//2016/Sjednice/Arhiva//37.\%20-\%201.pdf] Accessed 14 May 2020 
adult person conceived and born with the donated sperm, donated ovum or a donated embryo to access all information about his/her biological origin, including the identity of the donor. ${ }^{122}$ The legislator also prescribed the duty of the parents to inform their child, at the latest by the age of 18 , that he/she was conceived with donated gamete. ${ }^{123}$ Furthermore, in medically justified cases and when it is in the interest of a child's well-being, the access to the information about the gamete donor is made available to the legal representative and to the physician of the child conceived and born with donated gamete. ${ }^{124}$

On the other hand, the donor does not have the right to know the identity of women who gave birth and the child who was conceived and born from donor's gamete. ${ }^{125}$ The donor must be informed about the child's right to know his/her origin which includes information about the identity of the donor. ${ }^{126}$ In written and notarized form donor confirms that he/she is informed about the child's right and gives the consent that his/her gamete may be used in the procreative procedure. ${ }^{127}$ Thus, donation and usage of donor's gametes should be carried out only with the free, informed and written consent of the donor. ${ }^{128}$

The principle of the legal certainty seeks from legislator to clearly distinguish the question of maternity and paternity in case of the child conceived with the help of medical science. ${ }^{129}$ Determining the origin of the child conceived in the medically assisted procedure as well as contesting motherhood and paternity of a child is regulated in the Family Act. According to the Family Act, the mother of a child conceived with the donated gametes is a woman who gave birth to the child. ${ }^{130}$ It means that the mother of the child considers being the woman who gave birth to the child although the child is not originating from her. ${ }^{131}$ Therefore, it is not permitted to contest the maternity of a child if the woman who gave birth and

122 The Act on Medically Assisted Procreation (Official Gazette No. 86/12; hereinafter: Act on Medically Assisted Procreation 2012)

123 Parents are informed about this obligation in the counselling procedure that is conducted before the beginning of the procedure of medically assisted reproduction. See Article 13(4) of the Act on Medically Assisted Procreation 2012

124 Article 15(3) of the Act on Medically Assisted Procreation 2012

125 Article 19(4) of the Act on Medically Assisted Procreation 2012

126 Article 19(3) of the Act on Medically Assisted Procreation 2012

127 Article 19(2) of the Act on Medically Assisted Procreation 2012

128 Article 19(1) of the Act on Medically Assisted Procreation 2012

129 Hrabar, D., Podrijetlo djeteta začetog uz medicinski pomognutu oplodnju, in: Šimunić, V. et al.(eds.), Reprodukcijska endokrinologija i neplodnost - Medicinski pomognuta oplodnja IVF, Zagreb, 2012, p. 675

130 See Article 82(1) of the Family Act 2015

131 Hrabar, op. cit. note 129 , p. 675 
woman who donated gamete gave their consents to participate in that type of medical procedure, according to the provisions of the Act on Medically Assisted Procreation 2012. ${ }^{132} \mathrm{~A}$ father of a child conceived with donated gametes is deemed to be the mother's husband if the child is born during the duration of a marriage or three hundred days from the cessation of the marriage, and if he has given his consent that child may be conceived with donor's gamete according to special provisions of the Act on Medically Assisted Procreation 2012. ${ }^{133}$

Since the right to medically assisted procreation is granted to a full aged and legally competent woman and a man who are married or living in an extramarital union and who, concerning their age and general health, are capable for exercising parental care, legislator specially regulated paternity of extramarital spouse. ${ }^{134}$ The Act on Medically Assisted Procreation 2012 prescribes that prior the procedure, man is obliged to make a certified statement of acknowledgement of paternity of the child, and the woman has to make a certified statement of consent to the acknowledgement of paternity of the child. ${ }^{135}$ If those statements are given together with the consents to medically assisted procreation with donor's gamete, mother's extramarital spouse is deemed to be the father of a child. ${ }^{136}$ In other words, the law does not permit to contest the paternity of a child if consents have been given according to the provisions of the Act on Medically Assisted Procreation 2012. It is logical that "the court procedures, in that case, are not permitted as the medical expertise would show the incompatibility of the biological and legal parent". ${ }^{137}$

We may notice that provisions of the Act on Medically Assisted Procreation 2012 and Family Act 2015 that regulate child's right to know his/her origin is greatly harmonized with the requirements of international law (CRC and ECHR) and aim to favour the child's welfare.

\section{CONCLUSION}

Developments in medical science have made possible for some adults to become parents with the help of donated gamete. In that case, the child is considered to have been born to the parents who don't have the biological connection with him/her as they are only imitating the natural procreation. Although donation of gamete help many couples to become parents it can result with a serious breach of

\footnotetext{
132 Article 82 of the Family Act 2015

133 Article 83(1) of the Family Act 2015

134 See Article 4 of the Act on Medically Assisted Procreation 2012

135 Article 16(2) of the Act on Medically Assisted Procreation 2012

136 Article 83(2) of the Family Act 2015

137 Hrabar, op. cit. note 129, p. 675
} 
child's right to know his/hers origin if information about the paternal biological ancestry is purely and simply erased from the child's life.

The issue of access to information about child's origins concerns the essence of his/ hers identity and it is recognized as a conventional right in the CRC and derived from ECHR with the help of ECtHR case law. The respective sources of this right are Article 7 of the CRC which provides for the right to know one's parents and Article 8 of the ECHR which contains the right to respect for private life.

Despite such recognition of the importance of knowing one's genetic origins and identity, the law in the European states is not uniform as the ECtHR considers that each member state has a quite wide margin of appreciation in regulating such a right, as there is no "consensus amongst member states, regarding the relative importance of the issue at stake or the best ways to protect it, especially when it comes to moral questions or delicate ethical issues" 138 In that manner, the right to know origin may be restricted, or limited, where it conflicts with the protection of the rights of the donor. Accordingly, an unconditional right to identifying information about donor does not, in reality, exist. As an example, we may mention France and Sweden as two Member States with the opposite approach in balancing competing rights -the right of a child to know the origin and right of the donor to privacy. In France donor's right to anonymity may be restricted by medical reasons when some information's regarding donor may be reviled to the child while in Sweden donors are always obliged to revile to children conceived with their gamete information about their identity when children reach sufficient maturity except if they are conceived outside the Swedish hospitals which have competence for conducting artificial proceedings with donors gamete. In other words, in France the interest of donor usually precedes interest of the child while in Sweden the interest of child usually precedes interest of the donor.

In Croatia, the exercise of the child's right to know data about his/her origin is balanced by the principle of the child's well-being. The realization of that right when the child is minor is conditioned with the approval of the special commission for medically assisted reproduction who will disclose information only if it is in accordance with the welfare of the child. In that case, the access to information on the donor is not provided directly to the child but the child's legal representative or the physician of the child on their requests and only if there are medically justified reasons. When the child reaches a certain age, then he/she has the right to access all information on biological origin included the information about the donor's identity. Those provisions clearly define the primacy of the child's well-being

$138 \quad$ See infra chapter 2 and 3 
that should always prevail if the interest between the child and donor conflict. ${ }^{139}$ In the practice, those provisions can be consistently applied and implemented only if the legal parents fulfill their obligation to familiarize the child with the notion that he/she is conceived with donated gamete.

Above mentioned examples of legal regimes suggest the conclusion that is more than important to find the balance between confronted rights and interest behind the conflict of right to know origin and right to anonymity. In cases when we need to balance between rights of adults and children, children and their interests should not be ignored. One of the major reasons for advocating this is the recognition that secrecy of information about donor deprives the child of his/her right to know the nature of his/her conception and that is not in child's best interests. ${ }^{140}$ As the best interest of the child is one of the paramount principles, states should aim to ensure that child's right to access information about his/her origin is always recognized and protected.

\section{REFERENCES}

\section{BOOKS AND ARTICLES}

1. Alinčić, M., Medicinski pomognuta oplodnja i obiteljskopravni sukobi interesa, Zbornik Pravnog fakulteta u Zagrebu, vol. 56, no. 4, 2006, pp. 883-910

2. Baudouin J.-L., Labrusse-Riou C., Produire l'homme, de quell droit ? Étude juridique et éthique des procréation sartificielles, Paris, 1987

3. Besson, S. Enforcing the Child's Right to Know Her Origins: Contrasting Approaches Under the Convention on the Rights of the Child and the European Convention on Human Rights, International Journal of Law, Policy and the Family, vol. 21, Issue 2, 2007, pp. 137-159

4. Brunet, L.; Kunstmann, J-M., Gamete donation in France: the future of the anonymity doctrine, Medicine, Health Care, and Philosophy, vol. 16, no. 1, 2013, pp. 69-81

5. Brunet, L. Le principe de l'anonymat du donneur de gamétes a' l'épreuve de son contexte. Analyse des conceptions juridiques de l'identité. In: Jouannet, P.; Mieusset, R. (eds.), Donner et aprés? La procréation par don de spermatozoïdes avec ou sans anonymat, Berlin: Springer, 2010, pp. 235-252

6. Brunet, L., Des usages prote iformes de la nature: Essai de relecture du droit franc, ais de la filiation, in: Bonte, P.; Porqueres, E.; Wilgaux, J. (eds.), Largument de la filiation. Aux

139 In Croatian family law theory, there is a clearly defined position with which we agree that if a conflict of interest between child and adult person occur priority should be given to the interests of the child. See Alinčić, M., Medicinski pomognuta oplodnja i obiteljskopravni sukobi interesa, Zbornik Pravnog fakulteta u Zagrebu, vol. 56, no. 4, 2006, p. 904

140 Daniels, R. K.; Taylor, K., Secrecy and Openness in Donor Insemination, Politics and the Life Sciences, vol. 12, no. 2, 1993, p 159 
fondements des societies européennes et me'diterrane'ennes, Paris: Maison des sciences de l'homme, 2011, pp. 285-323

7. Carbonnier, J., Droit et passion du droit sous la VeRépublique, Flammarion, 1996, pp. 248250

8. Cadoret, A. et al., Les lois du silence, Libération, 2003

9. Clark, B., A Balancing Act? The Rights of Donor-Conceived Children to Know Their Biological Origins, Georgia Journal of International and Comparative Law, vol. 40, no. 3, 2012, pp. 619-661

10. Daniels, K.; Lalos, O., The Swedish insemination act and the availability of donors, Human Reproduction, vol.10, Nno.7, 1995, pp. 1871-1874

11. Daniels, K., The Swedish Insemination Act and Its Impact, The Australian and New Zealand Journal of Obstetrics and Gynecology, vol. 34, no. 4, 1994, pp.437-439

12. Daniels, R. K.; Taylor, K., Secrecy and Openness in Donor Insemination, Politics and the Life Sciences, vol. 12, no. 2, 1993, pp. 155-170

13. Dekeuwer-Defossez, F., Renover Le Droit de La Famille : Propositions Pour Un Droit Adapte Et Aux Aspirations de Notre Temps, Documentation Francais, 1999

14. Delaisi de Parseval, G.; Verdier, P., Enfant de personne, Paris: Odile Jacob, 1994

15. Eekelaar, J., Parenthood, Social Engineering and Rights, in: Morgan, D.; Douglas, G. (eds.), Constituting Families; a Study in Governance, Franz Steiner Verlag Stuttgart, 1994, pp 80-97

16. Ekerhovd, E.; Faurskov, A.; Werner, C., Swedish Sperm Donors Are Driven by Altruism, but Shortage of Sperm Donors Leads to Reproductive Travelling, Uppsala journal of medical sciences, vol. 113, no. 3, 2008, pp. 305-313

17. Farnós Amorós, E., Donor anonymity, or the right to know one's origins?, Catalan Social Sciences Review, vol. 5, Issue 5, 2015, pp. 1-10

18. Fortin, J., Children's right to know their origins - too far, too fast?,Child and Family Law Quarterly, vol. 21, no. 3, 2009, p. 336-355

19. Freeman, M., The new birth right? Identity and the child of the reproduction revolution, The International Journal of Children's Rights, vol. 4, Issue 3, 1996, pp. 273-297

20. Greer, S., The Margin of Appreciation: Interpretation and Discretion Under the European Convention on Human Rights, Council of Europe, 2000

21. Hrabar, D., Pravni dosezi medicinske oplodnje u Hrvatskoj, Zbornik Pravnog fakulteta u Zagrebu, vol. 60, no. 2, 2010, pp. 415-442

22. Hrabar, D., Podrijetlo djeteta začetog uz medicinski pomognutu oplodnju, in: Šimunić, V. et al.(eds.),Reprodukcijska endokrinologija I neplodnost - Medicinski pomognuta oplodnja IVF, Zagreb, 2012, pp. 671-676

23. Isaksson, S.et al., Two decades after legislation on identifiable donors in Sweden: are recipient couples ready to be open about using gamete donation?, Human Reproduction, vol. 26, no. 4, pp. 2011, pp. 853-860

24. Korać, A., Draft of the Croatian Act on Medically Assisted Procreation - Balancing Procreative Rights, Društvena istraživanja: časopis za opća društvena pitanja, vol. 8, no. 2-3, 1999, pp. 229-238 
25. Liljestrand, P., Legitimate State and Illegitimate Parents: Donor Insemination Politics in Sweden, Social Politics: International Studies in Gender, State \& Society, vol. 2, Issue 3, 1995, pp. 270-304

26. MacCormick, N., Legal Reasoning and Practical Reason, in: French/Ühling/Wettstein (eds.), Midwest Philosophical Studies VII: Social and Political Philosophy, Minneapolis, University of Minnesota Press, 1982

27. Marshall, J., Personal Freedom Through Human Rights Law?: Autonomy, Identity and Integrity Under the European Convention on Human Rights, International Studies in Human Rights, vol. 98, 2008

28. Masson, J.; Harrison, C., Identity: Mapping the frontiers, in: Loweand, N.; Douglas, G. (eds.), Families Across Frontiers, The Hague: M. Nijhoff, 1996, pp. 278 - 279

29. O’Donovan, K., A Right to Know One's Parentage?,International Journal of Law and the Family, International Journal of Law, Policy and the Family, vol. 2, Issue 1, 1988, pp. 27-45

30. O'Donovan, K., What Shall We Tell the Children?" Reflections on Children's Perspectives and the Reproduction Revolution; in Lee, R.; Morgan, D. (eds.), Birthrights: Law and Ethics at the Beginnings of Life. London: Routledge; 1989, pp. 96-114

31. Ravitsky, V., Knowing where you come from: The Rights of Donor-Conceived Individuals and the Meaning of Genetic Relatedness, Minnesota Journal of Law, Science and Technology, vol. 11, no. 2, 2010, pp. 655-684

32. Raz, J., On the Nature of Rights, Mind, vol. 93, no. 370, 1984, pp. 194-214

33. Raz, J., The Morality of Freedom, Oxford, 1986

34. Ronen, Y., Redefining the Child's Right to Identity, International Journal of Law, Policy and the Family, vol. 18, Issue 2, 2004, pp. 147-177

35. Steiner, E., Desperately Seeking Mother-Anonymous Births in the European Court of Human Rights, Child and Family Law Quarterly, vol. 15, no. 4, 2003, pp.425-448

36. Vacquin, M., Filiation et artifice, Le Supplément, 1991, pp. 130-149

37. Widlöcher, D.; Tomkiewicz S., Actes du Colloque "Génétique, procréation et droit», Paris: Actes Sud, 1985

38. Woodhouse, B. B., Hidden in Plain Sight: The Tragedy of Children's Rights from Ben Franklin to Lionel Tate, Princeton University Press, 2008

\section{LIST OF NATIONAL REGULATIONS, ACTS AND COURT DECISIONS}

1. Act on Medically Assisted Procreation (Official Gazette No. 88/09)

2. Act on Medically Assisted Procreation (Official Gazette No. 86/12)

3. Act on Health Measures Related to Right to the Enjoyment of Free Choice in Childbirth (Official Gazette No. 18/78, 31/86, 47/89)

4. Amendment of theAct on Medically Assisted Procreation (Official Gazette No. 137/2009)

5. Family Act (Official Gazette No. 16/03, 17/04, 136/04, 107/07, 57/11, 25/13, 05/15)

6. Family Act (Official Gazette No. 103/15, 89/19) 


\section{CASE LAW}

1. The case of Gaskin v. United Kingdom, Application no. 10454/83, Judgment of 7 July 1989, Series A, no. 160, 1989

2. The case of Godelli v. Italy, Application no. 33783/09, Judgment of 25 September 2012

3. The case of Jäggi v. Switzerland,Application no. 58757/00, Judgment of 13 July 2006

4. The case of Mikulic v. Croatia, Application no. 53176/99, Judgement of 7 February 2002

5. The case of Odièvre v. France, Application no. 42326/98, Judgement of 13 February 2003

\section{WEBSITE REFERENCES}

1. Act Concerning Measures for Purposes of Research or Treatment Involving Fertilised Human Ova (Lag om åtgärder i forsknings-eller behandlingssyfte med ägg frän människa,SFS 1991:115). [https://www.riksdagen.se/sv/dokument-lagar/dokument/svensk-forfattningssamling/lag-1991115-om-atgarder-i-forsknings--eller_sfs-1991-115] Accessed 20 April 2020

2. Act Concerning the use of Certain Genetic Technology in Medical Screening (Lag om användning av viss genteknik vid allmänna hälsoundersökningar, SFS 1991:114), [https://www. riksdagen.se/sv/dokument-lagar/dokument/svensk-forfattningssamling/lag-1991114-omanvandning-av-viss-genteknik_sfs-1991-114] Accessed 20 April 2020

3. Act on Insemination (Lag om insemination, SFS 1984:1140), [https://www.riksdagen.se/sv/ dokument-lagar/dokument/svensk-forfattningssamling/lag-19841140-om-insemination_ sfs-1984-1140] Accessed 20 April 2020

4. Blauwhoff, R.J., Foundational facts, relative truths: a comparative law study on children's right to know their genetic origins, Utrecht University Repository, 2009, [https://dspace.library. uu.nl/handle/1874/34380] Accessed 20 April 2020

5. Brunet, L., Donors anonymity and right to access to personal origin, Council of Europe, 2018, [www.eshre.eu >05_BRUNET_NEW] Accessed 20 April 2020

6. Civil code (Code Civil), [https://www.legifrance.gouv.fr/affichCode.do;jsession$\mathrm{id}=2 \mathrm{EACFC55F81B97B6B38B1080C0E4929D.tplgfr41s \_ 3?cidTexte=LEGITEX-}$ T000006070721\&date'Texte=20080225] Accessed 20 April 2020

7. European Convention for the Protection of Human Rights and Fundamental Freedoms, as amended by Protocols Nos. 11 and 14, 4 November 1950, ETS 5, available at: [https:// www.refworld.org/docid/3ae6b3b04.html] Accessed 20 April 2020

8. French Bioethics: Main Revisions Adopted by the Senate during First Reading, 2020, [https:// www.alliancevita.org/en/2020/02/french-bioethics-main-revisions-adopted-by-the-senateduring-first-reading/] Accessed 20 April 2020

9. Genetic Integrity Act (Lag om genetisk integritet, SFS 2006:351),[https://www.riksdagen.se/ sv/dokument-lagar/dokument/svensk-forfattningssamling/lag-2006351-om-genetisk-integritet-mm_sfs-2006-351] Accessed 20 April 2020

10. Isaksson, S., The child's best interest: Perspectives of gamete recipients and donors, Digital Comprehensive Summaries of Uppsala Dissertations from the Faculty of Medicine 1152, Uppsala University, 2015, [https://uu.diva-portal.org/smash/get/diva2:862603/FULLTEXT01. pdf] Accessed 20 April 2020 
11. IVF Act (Lag om befruktning utanför kroppen, SFS 1988:711), [https://riksdagen.se/sv/dokument-lagar/dokument/svensk-forfattningssamling/lag-1988711-om-befruktning-utanfor-kroppen_sfs-1988-711] Accessed 20 April 2020

12. Law no. 2002- 93 of $22^{\text {nd }}$ January 2002 (Loi $n^{\circ} 2002-93$ du 22 janvier 2002 relative à l'accès aux origines des personnesadoptées et pupilles de l'Etat) relating to access by adopted persons and people in State care to information about their origins, [https://www.legifrance.gouv.fr/ affich Texte.do?cidTexte=JORFTEXT000000361918\&categorieLien=id] Accessed 20 April 2020

13. Law no. 93-22 of $8^{\text {th }}$ January 1993 (Loi $n^{\circ}$ 93-22 du 8 janvier 1993 modifiant le code civil relative à l'état civil, à la famille et aux droits de l'enfant et instituant le juge aux affaires familiales, JORF n ${ }^{\circ} 7$ du 9 janvier 1993, p 495) inserting Articles 341 and 341-1 Civil Code (Code civil), [https://www.legifrance.gouv.fr/affichTexte.do?cidTexte=JORFTEXT000000361918\&categorieLien=id] Accessed 20 April 2020

14. Leroyer, A-M., Why should France change its legislation relating to donor anonymity?, 2016, pp. 23-24, [ejournals.lib.auth.gr.] Accessed 20 April 2020

15. Loi bioéthique: que reste-t-il du projet de loi qui arrive au Sénat?, 2020, [https://www.france24. $\mathrm{com} / \mathrm{fr} / 20200120$-loi-bio\%C3\%A9thique-que-reste-t-il-du-projet-de-loi-qui-arrive-aus\%C3\%A9nat] Accessed 20 April 2020

16. Public Health Code (Code de la santé publique). [https://www.legifrance.gouv.fr/affichCode. do?cidTexte=LEGITEXT000006072665] Accessed 20 April 2020

17. Social Action and Families Code (Code de L'action Sociale et des Familles). [https://www.legifrance.gouv.fr/affichCodeArticle.do?idArticle=LEGIARTI000006796699\&cidTexte=LEGITEXT000006074069\&dateTexte=20020123] Accessed 20 April 2020

18. Steering Committee of Bioethics (CDBI), Strasbourg, 9 February 2012, available at: [https://www.coe.int/t/dg3/healthbioethic/texts_and_documents/INF_2005_7\%20e\%20 REV2\%20MAP.pdf] Accessed 13 May 2020

19. Stoll, J., Swedish donor offspring and their legal right to information, Uppsala Universitet, Sweden, 2008, [https://www.diva-portal.org/smash/get/diva2:398198/FULLTEXT01.pdf] Accessed 20 April 2020

20. The case of Gauvin-Fournis v. France, Application no. 21424/16. Application communicated to the French Government on 5 June 2018. [https://hudoc.echr.coe.int/eng\#\{\%22itemid\%22:[\%22001-184370\%22]\}] Accessed 20 April2020

21. The case of Silliau v. France, Application no. 45728/17. Application communicated to the French Government on 5 June 2018. [https://hudoc.echr.coe.int/fre\#\{\%22itemid\%22:[\%22001-184371\%22]\}] Accessed 20 April 2020

22. The Final Draft on the Act on Medically Assisted Procreation, Government of the Republic of Croatia, p.44, available at: [https://vlada.gov.hr/UserDocsImages//2016/Sjednice/Arhiva//37.\%20-\%201.pdf] Accessed 14 May 2020

23. UN Committee on the Rights of the Child (CRC), UN Committee on the Rights of the Child: Concluding Observations: Denmark, 15 January 1995, CRC/C/15/Add.33, available at: [https://www.refworld.org/docid/3ae6aec817.html] Accessed 18 May 2020 
24. UN Committee on the Rights of the Child (CRC), UN Committee on the Rights of the Child: Concluding Observations: Norway, 25 April 1994, CRC/C/15/Add.23, available at: [https:// www.refworld.org/docid/3ae6aefe8.html] Accessed 18 May 2020

25. UN Committee on the Rights of the Child (CRC), UN Committee on the Rights of the Child: Concluding Observations: United Kingdom of Great Britain and Northern Ireland, 9 October 2002, CRC/C/15/Add.188, available at: [https://www.refworld.org/docid/3df58f087.html] Accessed 18 May 2020

26. UN General Assembly, Convention on the Rights of the Child, 20 November 1989, United Nations, Treaty Series, vol. 1577, p. 3, available at: [https://www.refworld.org/docid/3ae6b38f0.html] Accessed 20 April 2020 